\title{
Kinetics and Mechanism of the Pyridinolysis of Diisopropyl Thiophosphinic Chloride in Acetonitrile
}

\author{
Md. Ehtesham Ul Hoque and Hai Whang Lee* \\ Department of Chemistry, Inha University, Incheon 402-751, Korea. *E-mail: hwlee@inha.ac.kr \\ Received October 5, 2011, Accepted October 24, 2011
}

\begin{abstract}
The kinetic studies on the pyridinolysis of diisopropyl thiophosphinic chloride have been carried out in acetonitrile at $55.0^{\circ} \mathrm{C}$. The free energy correlations for substituent $\mathrm{X}$ variations in the $\mathrm{X}$-pyridines are biphasic concave upwards with a break point at $\mathrm{X}=3-\mathrm{Ph}$. A concerted $\mathrm{S}_{\mathrm{N}} 2$ mechanism is proposed with a change of the attacking direction of the X-pyridine from a frontside attack for the strongly basic pyridines to a backside attack for the weakly basic pyridines. The factors to determine the rates and thio effects on the rates for the pyridinolyses of thiophophinic chloride, chlorothiophosphate, phosphinic chloride, phosphonochloridothioate, and chlorophosphate systems are briefly reviewed on the basis of the magnitude of the positive charge of the reaction center $\mathrm{P}$ atom and steric effects of the two ligands.
\end{abstract}

Key Words : Phosphoryl transfer reaction, Pyridinolysis, Diisopropyl thiophosphinic chloride, Biphasic concave upward free energy relationship

\section{Introduction}

The kinetic studies of the pyridinolyses of tetracoordinated phosphorus in acetonitrile $(\mathrm{MeCN})$ have been studied extensively by this lab. ${ }^{1}$ Herein, the nucleophilic substitution reactions of diisopropyl thiophosphinic chloride (3) with substituted X-pyridines are investigated kinetically in $\mathrm{MeCN}$ at $55.0 \pm 0.1{ }^{\circ} \mathrm{C}$ (Scheme 1) to gain further information into the reactivity and mechanism depending on the variation of the two ligands. The pyridinolysis rates of the studied thiophophinic chloride $\left[\mathrm{R}_{1} \mathrm{R}_{2} \mathrm{P}(=\mathrm{S}) \mathrm{Cl}\right.$-type $]$, phosphinic chloride $\left[\mathrm{R}_{1} \mathrm{R}_{2} \mathrm{P}(=\mathrm{O}) \mathrm{Cl}\right.$-type $]$, chlorothiophosphate $\left[\left(\mathrm{R}_{1} \mathrm{O}\right)\left(\mathrm{R}_{2} \mathrm{O}\right) \mathrm{P}(=\mathrm{S})\right.$ Cl-type $]$, chlorophosphate $\left[\left(\mathrm{R}_{1} \mathrm{O}\right)\left(\mathrm{R}_{2} \mathrm{O}\right) \mathrm{P}\right.$ $(=\mathrm{O})$ Cl-type], and phosphonochloridothioate $\left[\mathrm{R}_{1}\left(\mathrm{R}_{2} \mathrm{O}\right) \mathrm{P}(=\mathrm{S})\right.$ Cl-type] systems in MeCN are discussed on the basis of the magnitude of positive charge of the reaction center $\mathrm{P}$ atom and steric effects of the two ligands. The so-called 'thio effect' on the rate difference between the $\mathrm{P}=\mathrm{O}$ and $\mathrm{P}=\mathrm{S}$ system is investigated for the pyridinolyses of tetracoordinated phosphorus.

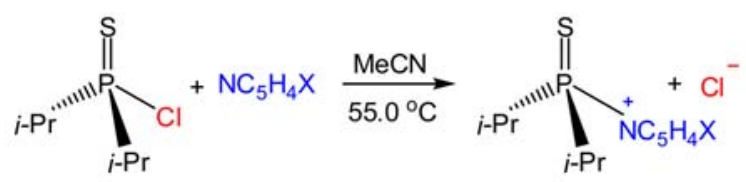

$\mathrm{X}=4-\mathrm{MeO}, 4-\mathrm{Me}, 3-\mathrm{Me}, \mathrm{H}, 3-\mathrm{Ph}, 3-\mathrm{MeO}$, 3-Cl, 3-Ac, 4-Ac, 3-CN

Scheme 1. The reactions of diisopropyl thiophosphinic chloride (3) with substituted X-pyridines in MeCN.

\section{Results and Discussion}

The reactions were carried out under pseudo-first-order conditions with a large excess of pyridine. The observed pseudo-first-order rate constants $\left(k_{\text {obsd }}\right)$ for all reactions obeyed eq. (1) with negligible $k_{0}(\approx 0)$ in $\mathrm{MeCN}$. The second-order rate constants were determined with at least five pyridine concentrations. The linear plots of eq. (1) suggest a lack of any base-catalysis or side reactions, and the overall reaction is described by Scheme 1 .

$$
k_{\mathrm{obsd}}=k_{0}+k_{2}\left[\mathrm{XC}_{5} \mathrm{H}_{4} \mathrm{~N}\right]
$$

The second-order rate constants $\left[k_{2}\left(\mathrm{M}^{-1} \mathrm{~s}^{-1}\right)\right]$ are summarized in Table 1 . The Brönsted $\beta_{\mathrm{X}}$ value was calculated by correlating $\log k_{2}(\mathrm{MeCN})$ with $\mathrm{p} K_{\mathrm{a}}\left(\mathrm{H}_{2} \mathrm{O}\right){ }^{2}$, which was justified theoretically and experimentally. ${ }^{3}$ The substituent effects of the nucleophiles upon the pyridinolysis rates correlate with those for a typical nucleophilic substitution reaction where the stronger nucleophile leads to a faster rate. However, both the Hammett (log $k_{2}$ vs $\rho_{\mathrm{x}}$; Fig. 1) and Brönsted [ $\log k_{2} v s \quad \mathrm{p} K_{\mathrm{a}}(\mathrm{X})$; Fig. 2] plots are biphasic concave upwards with a break point at $\mathrm{X}=3-\mathrm{Ph}$. The magnitudes of $\rho_{\mathrm{X}}(=-3.62)$ and $\beta_{\mathrm{X}}(=0.74)$ values with the strongly basic pyridines $(\mathrm{X}=4-\mathrm{MeO}, 4-\mathrm{Me}, 3-\mathrm{Me}, \mathrm{H}, 3-\mathrm{Ph})$ are greater than those $\left(\rho_{\mathrm{X}}=-0.90\right.$ and $\left.\beta_{\mathrm{X}}=0.14\right)$ with the weakly basic pyridines ( $\mathrm{X}=3-\mathrm{Ph}, 3-\mathrm{MeO}, 3-\mathrm{Cl}, 3-\mathrm{Ac}, 4-\mathrm{Ac}$, 3-CN).

The second-order rate constants $\left(k_{2}\right)$ with unsubstituted

Table 1. Second-Order Rate Constants $\left(k_{2} \times 10^{5} / \mathrm{M}^{-1} \mathrm{~s}^{-1}\right)$ of the Reactions of Diisopropyl Thiophosphinic Chloride $(3)$ with $\mathrm{XC}_{5} \mathrm{H}_{4} \mathrm{~N}$ in $\mathrm{MeCN}$ at $55.0^{\circ} \mathrm{C}$

\begin{tabular}{|c|c|c|c|c|c|c|c|c|c|c|}
\hline$X$ & $4-\mathrm{MeO}$ & $4-\mathrm{Me}$ & $3-\mathrm{Me}$ & $\mathrm{H}$ & $3-\mathrm{Ph}$ & 3-MeO & $3-\mathrm{Cl}$ & 3-Ac & $4-A c$ & $3-\mathrm{CN}$ \\
\hline$k_{2} \times 10^{5}$ & $137 \pm 1$ & $64.0 \pm 0.4$ & $27.7 \pm 0.1$ & $14.4 \pm 0.1$ & $9.04 \pm 0.06$ & $8.41 \pm 0.06$ & $4.99 \pm 0.02$ & $4.96 \pm 0.02$ & $3.79 \pm 0.03$ & $3.19 \pm 0.03$ \\
\hline
\end{tabular}




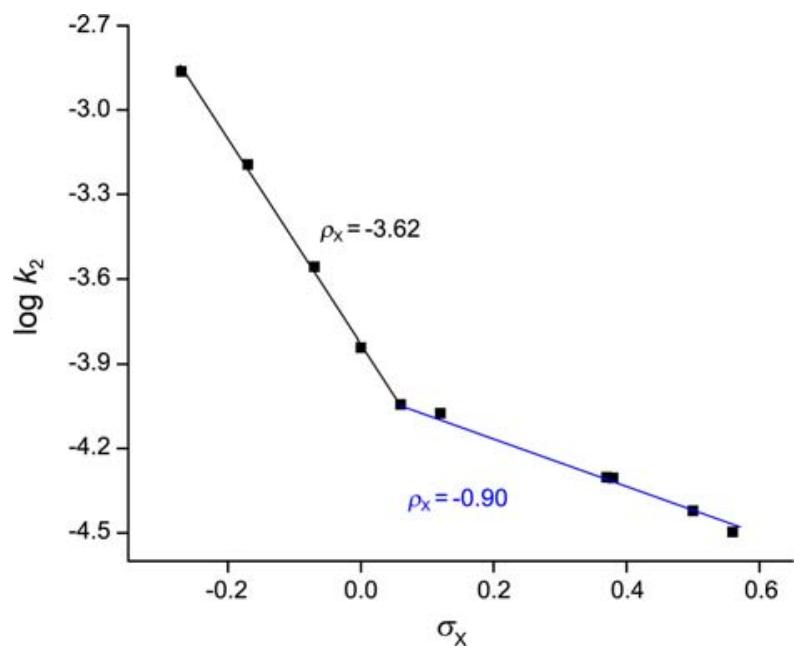

Figure 1. The Hammett plot $\left(\log k_{2} v s \sigma_{\mathrm{X}}\right)$ of the reactions of diisopropyl thiophosphinic chloride (3) with X-pyridines in $\mathrm{MeCN}$ at $55.0^{\circ} \mathrm{C}$. The values of $\rho_{\mathrm{X}}$ are $-3.62 \pm 0.02(\mathrm{r}=0.999)$ with $\mathrm{X}=(4-\mathrm{MeO}, 4-\mathrm{Me}, 3-\mathrm{Me}, \mathrm{H}, 3-\mathrm{Ph})$ and $-0.90 \pm 0.01(\mathrm{r}=0.998)$ with $\mathrm{X}=$ (3-Ph, 3-MeO, 3-Cl, 3-Ac, 4-Ac, 3-CN).

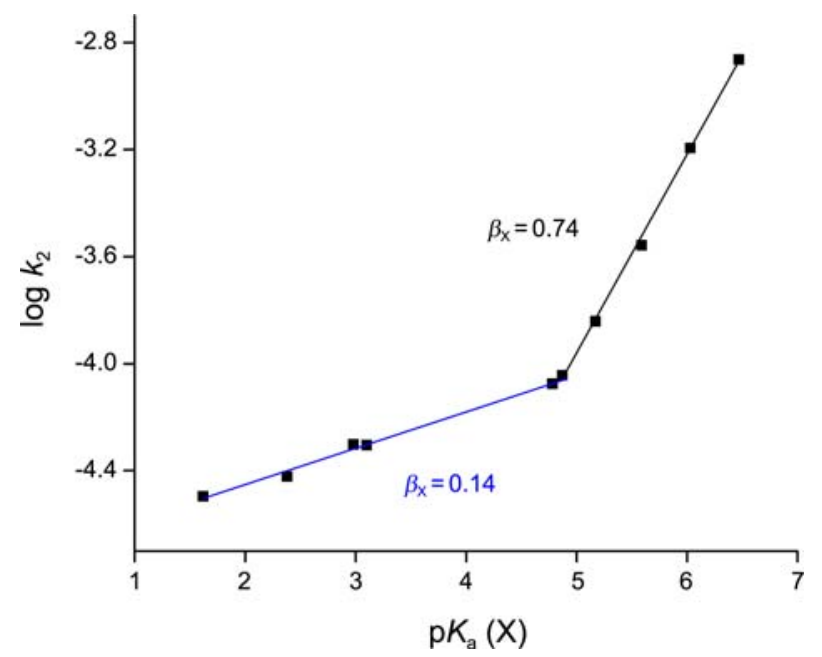

Figure 2. The Brönsted plot $\left[\log k_{2} v s \mathrm{p} K_{\mathrm{a}}(\mathrm{X})\right]$ of the reactions of diisopropyl thiophosphinic chloride (3) with X-pyridines in $\mathrm{MeCN}$ at $55.0^{\circ} \mathrm{C}$. The values of $\beta_{\mathrm{X}}$ are $0.74 \pm 0.02(\mathrm{r}=0.999)$ with $\mathrm{X}=(4-\mathrm{MeO}, 4-\mathrm{Me}, 3-\mathrm{Me}, \mathrm{H}, 3-\mathrm{Ph})$ and $0.14 \pm 0.02(\mathrm{r}=0.997)$ with $\mathrm{X}=$ (3-Ph, 3-MeO, 3-Cl, 3-Ac, 4-Ac, 3-CN).

Table 2. Summary of the Second-Order Rate Constants $\left(k_{2}\right.$ with $\mathrm{C}_{5} \mathrm{H}_{5} \mathrm{~N}$ at $\left.35 .{ }^{\circ} \mathrm{C}\right)$, NBO Charges at the Reaction Center P Atom, Summations of the Taft's Steric Constants $\left(\Sigma E_{\mathrm{S}}\right)$ of the Two Ligands, and Brönsted Coefficients $\left(\beta_{\mathrm{X}}\right)$ for the Pyridinolyses of Thiophosphinic Chloride system $(\mathbf{1}, \mathbf{2}, \mathbf{3}$, and $\mathbf{4})$ in $\mathrm{MeCN}$

\begin{tabular}{cccccc}
\hline Substrate & $k_{2} \times 10^{3 a}$ & Charge at $\mathrm{P}$ & $-\sum E_{\mathrm{S}}$ & $\beta_{\mathrm{X}}$ & Ref. \\
\hline 1: $\mathrm{S}(\mathrm{Me}, \mathrm{Me})$ & 0.744 & 1.180 & 0 & $0.97 / 0.27^{d}$ & $1 \mathrm{~h}$ \\
:: $\mathrm{S}(\mathrm{Et}, \mathrm{Et})$ & 0.0960 & 1.208 & 0.14 & $0.92 / 0.34^{d}$ & $1 \mathrm{p}$ \\
3: $\mathrm{S}(i-\mathrm{Pr}, i-\mathrm{Pr})$ & $0.0760^{b}$ & 1.247 & 0.94 & $0.74 / 0.14^{d}$ & this work \\
$\mathbf{4 :} \mathrm{S}(\mathrm{Ph}, \mathrm{Ph})$ & $1.83^{c}$ & 1.236 & 4.96 & $1.53 / 0.38^{d}$ & $1 \mathrm{~d}$ \\
\hline
\end{tabular}

${ }^{a}$ Second-order rate constant with unsubstituted pyridine $(\mathrm{X}=\mathrm{H})$ at $35.0^{\circ} \mathrm{C} .{ }^{b}$ Empirical kinetic data. See ref. 4. ${ }^{c}$ Extrapolated value in the Arrhenius plot with kinetic data: $k_{2}=0.371,0.940$, and $1.35 \times 10^{-3} \mathrm{M}^{-1} \mathrm{~s}^{-1}$ at $5.0,15.0$, and $25.0^{\circ} \mathrm{C}$, respectively, from ref. $3 .{ }^{d}$ Strongly/weakly basic pyridines.

pyridine $\left(\mathrm{C}_{5} \mathrm{H}_{5} \mathrm{~N}\right)$ at $35.0{ }^{\circ} \mathrm{C}$, natural bond order $(\mathrm{NBO})$ charges at the reaction center $\mathrm{P}$ atom in the gas phase $[B 3 L Y P / 6-311+G(d, p)$ level of theory $],{ }^{5}$ summations of the Taft's steric constants $\left[E_{\mathrm{S}}=E_{\mathrm{S}}\left(\mathrm{R}_{1}\right)+E_{\mathrm{S}}\left(\mathrm{R}_{2}\right)\right]^{6}$ of the two ligands, and Brönsted coefficients $\left(\beta_{\mathrm{X}}\right)$ for the pyridinolyses of four thiophosphinic chloride system $\left[\mathrm{R}_{1} \mathrm{R}_{2} \mathrm{P}(=\mathrm{S}) \mathrm{Cl}\right.$-type $]$ in $\mathrm{MeCN}$ are summarized in Table 2. When the magnitude of the positive charge of the reaction center $\mathrm{P}$ atom in the substrate plays an important role to determine the pyridinolysis rate, the sequence of the pyridinolysis rate should be $\mathbf{3}>\mathbf{4}>\mathbf{2}>\mathbf{1}$. On the other hand, when the steric effects of the two ligands, $\mathrm{R}_{1}$ and $\mathrm{R}_{2}$, play an important role, the sequence of the rate should be $\mathbf{1}>\mathbf{2}>\mathbf{3}>\mathbf{4}$. However, the observed sequence of the pyridinolyses rates of $\mathbf{4}>\mathbf{1}>\mathbf{2}$ $>\mathbf{3}$ [the relative rate ratio of 24(4):9.8(1):1.3(2):1(3)] does not show systematic consistency with the NBO charge at $\mathrm{P}$ atom or $E_{\mathrm{S}}$ of the two ligands. These results indicate that the pyridinolysis rates of thiophosphinic chloride system in $\mathrm{MeCN}$ are not dependent upon one dominant factor but on many factors.

The second-order rate constants $\left(k_{2}\right)$ with $\mathrm{C}_{5} \mathrm{H}_{5} \mathrm{~N}$ at $35.0^{\circ} \mathrm{C}$, relative rate ratios, and NBO charges at the reaction center $\mathrm{P}$ atom for the pyridinolyses of chlorothiophophate $\left[\left(\mathrm{R}_{1} \mathrm{O}\right)\right.$ $\left(\mathrm{R}_{2} \mathrm{O}\right) \mathrm{P}(=\mathrm{S}) \mathrm{Cl}$-type $]$, phosphonochloridothioate $\left[\mathrm{R}_{1}\left(\mathrm{R}_{2} \mathrm{O}\right) \mathrm{P}\right.$
(=S)Cl-type], phosphinic chloride $\left[\mathrm{R}_{1} \mathrm{R}_{2} \mathrm{P}(=\mathrm{O})\right.$ Cl-type $]$, and chlorophosphate $\left[\left(\mathrm{R}_{1} \mathrm{O}\right)\left(\mathrm{R}_{2} \mathrm{O}\right) \mathrm{P}(=\mathrm{O})\right.$ Cl-type $]$ systems in MeCN are summarized in Table 3. The sequence of substrates in each system follows the size of the two ligands. Henceforth, for convenience to express the substrate, the $\mathrm{P}=\mathrm{O}$ and $\mathrm{P}=\mathrm{S}$ systems are denoted as $\mathrm{O}$ and $\mathrm{S}$, respectively, and the two ligands are represented in parenthesis. The rates of chlorothiophosphate system with unsubstituted pyridine in $\mathrm{MeCN}$ at $35.0^{\circ} \mathrm{C}$ give the relative rate ratio of $11.2[\mathrm{~S}(\mathrm{MeO}, \mathrm{MeO})]$ : 8.7[S(EtO,EtO)]:2.4[S(PhO,PhO)]:1[S(EtO,PhO)], indicating that the pyridinolysis rates are not dependent upon one dominant factor. In the case of phosphonochloridothioate system, the trends of the pyridinolysis rates depending on the two ligands are hard to say because of the lack of information. Meanwhile, the reaction rates of phosphinic chloride system with unsubstituted pyridine in $\mathrm{MeCN}$ at $35.0^{\circ} \mathrm{C}$ give the relative ratio of $7.59 \times 10^{6}[\mathrm{O}(\mathrm{Me}, \mathrm{Ph})]$ : $6.14 \times 10^{6}[\mathrm{O}(\mathrm{Me}, \mathrm{Me})]: 7.65 \times 10^{3}[\mathrm{O}(\mathrm{Et}, \mathrm{Et})]: 3.29 \times 10^{3}[\mathrm{O}(\mathrm{Ph}$, $\mathrm{Ph})]: 1[\mathrm{O}(\mathrm{cHex}, \mathrm{cHex})]$ where the rates are strongly dependent upon the two ligands and the rates are not dependent upon one dominant factor but on many factors. In the case of chlorophosphate system, the relative rate ratio of 27.7 [O $(\mathrm{PhO}, \mathrm{PhO})]: 6.7[\mathrm{O}(\mathrm{MeO}, \mathrm{MeO})]: 5.5[\mathrm{O}(\mathrm{EtO}, \mathrm{EtO})]: 3.7[\mathrm{O}(\mathrm{Et}$ $\mathrm{O}, \mathrm{PhO})]: 1[(i-\mathrm{PrO}, i-\mathrm{PrO})]$ also indicates that the rates are 
Table 3. Summary of the Second-Order Rate Constants $\left(k_{2}\right.$ with $\mathrm{C}_{5} \mathrm{H}_{5} \mathrm{~N}$ at $35.0^{\circ} \mathrm{C}$ ), Relative Rate Ratios, and NBO Charges at the Reaction Center P Atom for the Pyridinolyses of Chlorothiophophate, Phosphonochloridothioate, Phosphinic chloride, and Chlorophosphate Systems in $\mathrm{MeCN}$

\begin{tabular}{|c|c|c|c|c|c|}
\hline System & Substrate & $k_{2} \times 10^{3 a}$ & Rate ratio & Charge at $\mathrm{P}$ & Ref. \\
\hline \multirow{4}{*}{$\begin{array}{c}\text { chlorothiophosphate } \\
\left(\mathrm{R}_{1} \mathrm{O}\right)\left(\mathrm{R}_{2} \mathrm{O}\right) \mathrm{P}(=\mathrm{S}) \mathrm{Cl} \text {-type }\end{array}$} & $\mathrm{S}(\mathrm{MeO}, \mathrm{MeO})$ & $1.54^{* b}$ & 11.2 & 1.687 & $1 \mathrm{~g}$ \\
\hline & $\mathrm{S}(\mathrm{EtO}, \mathrm{EtO})$ & $1.19^{*}$ & 8.7 & 1.701 & $1 \mathrm{~g}$ \\
\hline & $\mathrm{S}\left(\mathrm{EtO}, \mathrm{YC}_{6} \mathrm{H}_{4} \mathrm{O}\right)$ & 0.137 & 1 & 1.687 & $1 \mathrm{~s}$ \\
\hline & $\mathrm{S}\left(\mathrm{PhO}, \mathrm{YC}_{6} \mathrm{H}_{4} \mathrm{O}\right)$ & 0.333 & 2.4 & 1.661 & $1 \mathrm{j}$ \\
\hline \multirow{2}{*}{$\begin{array}{l}\text { phosphonochloridothioate } \\
\mathrm{R}_{1}\left(\mathrm{R}_{2} \mathrm{O}\right) \mathrm{P}(=\mathrm{S}) \text { Cl-type }\end{array}$} & $\mathrm{S}\left(\mathrm{Me}, \mathrm{YC}_{6} \mathrm{H}_{4} \mathrm{O}\right)$ & 14.3 & 1.3 & 1.432 & $1 \mathrm{k}$ \\
\hline & $\mathrm{S}\left(\mathrm{Ph}, \mathrm{YC}_{6} \mathrm{H}_{4} \mathrm{O}\right)$ & 11.2 & 1 & 1.462 & $1 \mathrm{f}$ \\
\hline \multirow{5}{*}{$\begin{array}{l}\text { phosphinic chloride } \\
\mathrm{R}_{1} \mathrm{R}_{2} \mathrm{P}(=\mathrm{O}) \text { Cl-type }\end{array}$} & $\mathrm{O}(\mathrm{Me}, \mathrm{Me})$ & $102,000^{*}$ & $6.14 \times 10^{6}$ & 1.793 & $1 \mathrm{~h}$ \\
\hline & $\mathrm{O}(\mathrm{Et}, \mathrm{Et})$ & 127 & $7.65 \times 10^{3}$ & 1.817 & $1 \mathrm{i}$ \\
\hline & $\mathrm{O}(\mathrm{Me}, \mathrm{Ph})$ & $126,000^{*}$ & $7.59 \times 10^{6}$ & 1.821 & $1 \mathrm{~m}$ \\
\hline & $\mathrm{O}(\mathrm{Ph}, \mathrm{Ph})$ & 54.6 & $3.29 \times 10^{3}$ & 1.844 & $1 d$ \\
\hline & $\mathrm{O}(\mathrm{cHex}, \mathrm{cHex})$ & 0.0166 & 1 & 1.863 & ln \\
\hline \multirow{4}{*}{$\begin{array}{c}\text { chlorophosphate } \\
\left(\mathrm{R}_{1} \mathrm{O}\right)\left(\mathrm{R}_{2} \mathrm{O}\right) \mathrm{P}(=\mathrm{O}) \mathrm{Cl} \text {-type }\end{array}$} & $\mathrm{O}(\mathrm{MeO}, \mathrm{MeO})$ & 64.7 & 6.7 & 2.226 & $1 \mathrm{~g}$ \\
\hline & $\mathrm{O}(\mathrm{EtO}, \mathrm{EtO})$ & 52.8 & 5.5 & 2.236 & $1 \mathrm{~g}$ \\
\hline & $\mathrm{O}(i$-PrO,$i-\mathrm{PrO})$ & 9.60 & 1 & 2.269 & $1 q$ \\
\hline & $\mathrm{O}\left(\mathrm{PhO}, \mathrm{YC}_{6} \mathrm{H}_{4} \mathrm{O}\right)$ & $266^{*}$ & 27.7 & 2.230 & 1a \\
\hline
\end{tabular}

${ }^{a}$ In the case of the presence $\mathrm{Y}$ substituent in the substrate, the second-order rate constant is with $\mathrm{Y}=\mathrm{H} .{ }^{b}$ The superscript of asterisk indicates that the second-order rate constant at $35.0^{\circ} \mathrm{C}$ is obtained by extrapolation in the Arrhenius plot.

Table 4. Second-Order Rate Constants of the Pyridinolysis of the $\mathrm{P}=\mathrm{O}$ and $\mathrm{P}=\mathrm{S}$ Systems $\left(k_{2}\right.$ with $\mathrm{C}_{5} \mathrm{H}_{5} \mathrm{~N}$ at $35.0^{\circ} \mathrm{C}$ ), Differences of Positive Charge at the Reaction Center $\mathrm{P}$ Atom, and Rate Ratios of $\mathrm{P}=\mathrm{O}$ and $\mathrm{P}=\mathrm{S}$ Systems

\begin{tabular}{ccccc}
\hline Two ligands & $10^{3} k_{2}(\mathrm{P}=\mathrm{O})$ & $10^{3} k_{2}(\mathrm{P}=\mathrm{S})$ & $\Delta($ Charge at $\mathrm{P})$ & $k_{2}(\mathrm{P}=\mathrm{O}) / k_{2}(\mathrm{P}=\mathrm{S})$ \\
\hline$(\mathrm{Me}, \mathrm{Me})$ & 102,000 & 0.744 & $1.793-1.180=0.613$ & 137,000 \\
$(\mathrm{Et}, \mathrm{Et})$ & 127 & 0.0960 & $1.817-1.208=0.609$ & 1,320 \\
$(\mathrm{Ph}, \mathrm{Ph})$ & 54.6 & 1.83 & $1.844-1.236=0.608$ & 30 \\
$(\mathrm{MeO}, \mathrm{MeO})$ & 64.7 & 1.54 & $2.226-1.687=0.539$ & 42 \\
$(\mathrm{EtO}, \mathrm{EtO})$ & 52.8 & 1.19 & $2.236-1.701=0.535$ & 44 \\
$(\mathrm{PhO}, \mathrm{PhO})$ & 266 & 0.333 & $2.230-1.661=0.569$ & 799 \\
\hline
\end{tabular}

not dependent upon one predominant factor. The authors conclude that the pyridinolysis rates of mentioned systems are not dependent upon one major factor but many factors. On the contrary, the anilinolysis rates of the thiophosphinic chloride, phosphinic chloride, chlorothiophosphate, and chlorophosphate systems are predominantly dependent upon the steric effects of the two ligands. ${ }^{7}$

The second-order rate constants of the pyridinolyses of the $\mathrm{P}=\mathrm{O}$ and $\mathrm{P}=\mathrm{S}$ systems (with $\mathrm{C}_{5} \mathrm{H}_{5} \mathrm{~N}$ at $35.0{ }^{\circ} \mathrm{C}$ ), differences of positive charge (NBO charge) at the reaction center $\mathrm{P}$ atom $[\Delta($ charge at $\mathrm{P})=($ charge at $\mathrm{P}$ with $\mathrm{P}=\mathrm{O})-($ charge at $\mathrm{P}$ with $\mathrm{P}=\mathrm{S})]$, and rate ratios of $\mathrm{P}=\mathrm{O}$ and $\mathrm{P}=\mathrm{S}$ systems $\left[k_{2}\right.$ $(\mathrm{P}=\mathrm{O}) / k_{2}(\mathrm{P}=\mathrm{S})$ ] are summarized in Table 4 . It is well known that the $\mathrm{P}=\mathrm{O}$ systems are generally more reactive than their $\mathrm{P}=\mathrm{S}$ counterparts for several reasons, the so-called 'thio effect', which is mainly the electronegativity difference between $\mathrm{O}$ and $\mathrm{S}$ and favors $\mathrm{O}$ over $\mathrm{S} .{ }^{8}$ The magnitude of the positive charge of the reaction center $\mathrm{P}$ atom for the $\mathrm{P}=\mathrm{O}$ system are greater $(0.54-0.61)$ than that for its $\mathrm{P}=\mathrm{S}$ counterpart system which may represent the electronegativity difference between $\mathrm{O}$ and $\mathrm{S}$, although the calculated NBO charges are not in $\mathrm{MeCN}$ but in the gas phase. However, the obtained range of the order of magnitudes of $k_{2}(\mathrm{P}=\mathrm{O})$ /
$k_{2}(\mathrm{P}=\mathrm{S})=10^{1}-10^{5}$ is too wide to be substantiated only by the electronegativity difference between $\mathrm{O}$ and $\mathrm{S}$. The variation trends of $k_{2}(\mathrm{P}=\mathrm{O}) / k_{2}(\mathrm{P}=\mathrm{S})$ do not show systematic consistency depending on the two ligands, and more experimental data should be accumulated to clarify the thio effects.

Focus will now shift to the reaction mechanism. As seen in Table 2, all the Brönsted plots for the pyridinolyses of four thiophosphinic chlorides (1-4) show biphasic concave upwards with a break point $(\mathrm{X}=\mathrm{H}$ with $\mathbf{1}$ and $\mathrm{X}=3-\mathrm{Ph}$ with $\mathbf{2 , 3}$, and 4). The $\beta_{\mathrm{X}}$ values with the strongly basic pyridines are greater than those with the weakly basic pyridines. The $\beta_{\mathrm{X}}$ value of 4 with the strongly basic pyridines is somewhat large and those of $\mathbf{3}$ (present work) are more or less small. In general, the nonlinear free energy correlation of a concave upward plot is diagnostic of a change in the reaction mechanism, such as parallel reactions where the reaction path is changed depending on the substituents, while nonlinear free energy correlation of the biphasic concave downward plot is diagnostic of a rate-limiting step change from bond breaking with less basic nucleophiles to bond formation with more basic nucleophiles. ${ }^{9}$ It is the suggestion of the authors that the concave upward Hammett and Brönsted plots can also be diagnostic of a change in the 


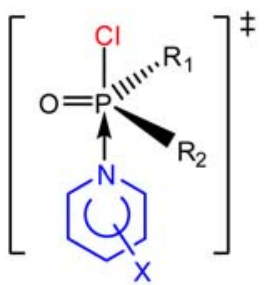

TSb

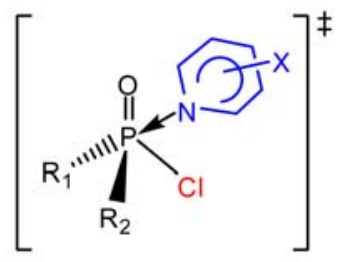

TSf
Scheme 2. Backside attack TSb and frontside attack TSf.

attacking direction of the nucleophile depending on the substituents from backside to frontside. ${ }^{1 \mathrm{~g}}$ It is worthy of note that a frontside attack TSf yields greater magnitudes of $\rho_{\mathrm{X}}$ and $\beta_{\mathrm{X}}$ values compared to a backside attack TSb (Scheme 2). ${ }^{1 \mathrm{c}}$

Thus, a concerted mechanism with a dominant backside nucleophilic attack (TSb) for more basic pyridines and with a dominant frontside nucleophilic attack (TSf) for less basic pyridines was proposed on the basis of concave upward free energy correlation and greater magnitudes of selectivity parameters with more basic pyridines for the pyridinolysis of 1 and 2 . In the present work, a concerted $\mathrm{S}_{\mathrm{N}} 2$ mechanism is proposed and biphasic concave upward free energy correlations is rationalized by a change of nucleophilic attacking direction from a frontside attack TSf $\left(\beta_{\mathrm{X}}=0.74\right)$ with the strongly basic pyridines to a backside attack (TSb; $\beta_{\mathrm{X}}=0.14$ ) with the weakly basic pyridines.

In the case of the pyridinolysis of $\mathbf{4}$, however, the $\beta_{\mathrm{X}}$ value of 1.53 with more basic pyridines strongly suggests a stepwise mechanism with a rate-limiting leaving group expulsion from the intermediate involving a frontside attack. This suggestion is supported by the $\beta_{\mathrm{X}}$ values of 1.36-2.33 involving a stepwise mechanism with a rate-limiting bond breaking step for the pyridinolyses of: ${ }^{10} \mathrm{~S}\left(\mathrm{EtO}, \mathrm{YC}_{6} \mathrm{H}_{4} \mathrm{O}\right)$ with $\beta_{\mathrm{X}}=2.31-2.33{ }^{1 \mathrm{~s}} \mathrm{~S}\left(\mathrm{PhO}, \mathrm{YC}_{6} \mathrm{H}_{4} \mathrm{O}\right)$ with $\beta_{\mathrm{X}}=1.36-1.50 ;{ }^{1 \mathrm{j}}$ and $\mathrm{S}\left(\mathrm{Ph}, \mathrm{YC}_{6} \mathrm{H}_{4} \mathrm{~S}\right)$ with $\beta_{\mathrm{X}}=1.42-1.49 .{ }^{1 \mathrm{r}}$ A concerted $\mathrm{S}_{\mathrm{N}} 2$ process with direct backside nucleophilic attack (or a stepwise mechanism with a rate-limiting bond formation) is proposed for less basic pyridines.

\section{Experimental Section}

Materals. Diisopropyl thiophosphinic chloride was prepared as described previously. ${ }^{7 \mathrm{r}}$ GR grade pyridines and HPLC grade acetonitrile (less than $0.005 \%$ water content) were used without further purification.

Kinetic Procedure. Conductometric rate measurements were carried out using self-made computer-aided automatic A/D converter conductivity bridges. ${ }^{1,7}$ Pseudo-first-order rate constants, $k_{\text {obsd, }}$, were measured by curve fitting analysis in origin program with a large excess of pyridines, $[$ Substrate $]=5 \times 10^{3} \mathrm{M}$ and [Pyridine] $=0.1-0.5 \mathrm{M}$. Secondorder rate constants, $k_{2}$, were obtained from the slope of a plot of $k_{\text {obsd }} v s$ [X-Pyridine]. The Pseudo-first-order rate constant values $\left(k_{\mathrm{obsd}}\right)$ were the average of at least three runs that were reproducible within $\pm 3 \%$.

Product Analysis. Diisopropyl thiophosphinic chloride was reacted with excess 3-chloropyridine, for more than 15 half-lives at $55.0{ }^{\circ} \mathrm{C}$ in $\mathrm{MeCN}$. Acetonitrile was removed under reduced pressure. The product was isolated by adding ether and insoluble fraction was collected. The product was purified to remove excess pyridine by washing several times with ether. Analytical and spectroscopic data of the product are as follows:

$\left[(\boldsymbol{i}-\mathbf{P r})_{2} \mathbf{P}(=\mathbf{S}) \mathrm{NC}_{5} \mathbf{H}_{4}-3-\mathrm{Cl}^{+} \mathbf{C l}^{-}\right.$. Light-yellow gummy-substance; ${ }^{1} \mathrm{H}$ NMR (400 MHz, $\left.\mathrm{CDCl}_{3}\right) \delta 1.21-1.32(12 \mathrm{H}, \mathrm{m}$, $\left.4 \mathrm{CH}_{3}, i-\mathrm{Pr}\right), 2.35-2.45(2 \mathrm{H}, \mathrm{m}, 2 \mathrm{CH}, i-\mathrm{Pr}), 7.20(1 \mathrm{H}, \mathrm{s}$, pyridinium), 7.61 (1H, s, pyridinium), $8.44(1 \mathrm{H}, \mathrm{s}$, pyridinium), 8.52 (1H, s, pyridinium); ${ }^{13} \mathrm{C}$ NMR $\left(100 \mathrm{MHz}, \mathrm{CDCl}_{3}\right) \delta$ 15.86-16.15 $\left(\mathrm{CH}_{3}, i-\mathrm{Pr}\right), 34.63,35.13(\mathrm{CH}, i-\mathrm{Pr}), 124.23$, 132.05, 135.79, 147.24, 148.57 ( $\mathrm{C}=\mathrm{C}$, pyridinium); ${ }^{31} \mathrm{P}$ NMR (162 MHz, $\left.\mathrm{CDCl}_{3}\right) \delta 91.90(1 \mathrm{P}, \mathrm{s}, \mathrm{P}=\mathrm{S}) ; m / z 298$ $\left(\mathrm{M}^{+}\right)$.

Acknowledgments. This work was supported by Inha University Research Grant and the Brain Korea 21 Program from National Research Foundation of Korea.

\section{References and Notes}

1. (a) Guha, A. K.; Lee, H. W.; Lee, I. J. Org. Chem. 2000, 65, 12. (b) Lee, H. W.; Guha, A. K.; Kim, C. K.; Lee, I. J. Org. Chem. 2002, 67, 2215. (c) Adhikary, K. K.; Lee, H. W.; Lee, I. Bull. Korean Chem. Soc. 2003, 24, 1135. (d) Hoque, M. E. U.; Dey, N. K.; Guha, A. K.; Kim, C. K.; Lee, B. S.; Lee, H. W. Bull. Korean Chem. Soc. 2007, 28, 1797. (e) Adhikary, K. K.; Lumbiny, B. J.; Kim, C. K.; Lee, H. W. Bull. Korean Chem. Soc. 2008, 29, 851. (f) Lumbiny, B. J.; Adhikary, K. K.; Lee, B. S.; Lee, H. W. Bull. Korean Chem. Soc. 2008, 29, 1769. (g) Dey, N. K.; Hoque, M. E. U.; Kim, C. K.; Lee, H. W. J. Phys. Org. Chem. 2010, 23, 1022. (h) Dey, N. K.; Adhikary, K. K.; Kim, C. K.; Lee, H. W. Bull. Korean Chem. Soc. 2010, 31, 3856. (i) Dey, N. K.; Kim, C. K.; Lee, H. W. Bull. Korean Chem. Soc. 2011, 32, 709. (j) Hoque, M. E. U.; Dey, S.; Kim, C. K.; Lee, H. W. Bull. Korean Chem. Soc. 2011, 32, 1138. (k) Guha, A. K.; Hoque, M. E. U.; Lee, H. W. Bull. Korean Chem. Soc. 2011, 32, 1375. (1) Guha, A. K.; Kim, C. K.; Lee, H. W. J. Phys. Org. Chem. 2011, 24, 474. (m) Adhikary, K. K.; Lee, H. W. Bull. Korean Chem. Soc. 2011, 32, 1945. (n) Hoque, M. E. U.; Lee, H. W. Bull. Korean Chem. Soc. 2011, 32, 2109. (o) Barai, H. R.; Lee, H. W. Bull. Korean Chem. Soc. 2011, 32, 2339. (p) Hoque, M. E. U.; Lee, H. W. Bull. Korean Chem. Soc. 2011, 32, 2805. (q) Hoque, M. E. U.; Lee, H. W. Bull. Korean Chem. Soc. 2011, 32, 3505. (r) Adhikary, K. K.; Lumbiny, B. J.; Lee, H. W. Bull. Korean Chem. Soc. 2011, 32, 3743. (s) Adhikary, K. K.; Lee, H. W. Bull. Korean Chem. Soc. 2011, 32, 3947.

2. (a) Fischer, A.; Galloway, W. J.; Vaughan, J. J. Chem. Soc. 1964, 3591. (b) Dean, J. A. Handbook of Organic Chemistry; McGrawHill: New York, 1987; Chapter 8. (c) Castro, E. A.; Freudenberg, M. J. Org. Chem. 1980, 45, 906.

3. (a) Lee, I.; Kim, C. K.; Han, I. S.; Lee, H. W.; Kim, W. K.; Kim, Y. B. J. Phys. Chem. B 1999, 103, 7302. (b) Coetzee, J. F. Prog. Phys. Org. Chem. 1967, 4, 45.

4. The second-order rate constants of $0.0760 \pm 0.0007,0.104 \pm 0.001$, and $0.144 \pm 0.001 \times 10^{-3} \mathrm{M}^{-1} \mathrm{~s}^{-1}$ are obtained at 35.0, 45.0, and $55.0^{\circ} \mathrm{C}$, respectively. Enthalpy and entropy of activation are $\Delta H^{\mp}=5.8 \pm 0.2 \mathrm{kcal} / \mathrm{mol}$ and $\Delta S^{\neq}=-59 \pm 1$ eu.

5. Hehre, W. J.; Random, L.; Schleyer, P. V. R.; Pople, J. A. Ab Initio Molecular Orbital Theory; Wiley: New York, 1986; Chapter 4.

6. (a) Taft, R. W. Steric Effect in Organic Chemistry; Newman, M. S., Ed.; Wiley: New York, 1956; Chapter 3. (b) Exner, O. Correlation Analysis in Chemistry: Recent Advances; Chapman, N. 
B., Shorter, J., Eds.; Plenum Press: New York, 1978; p 439.

7. (a) Hoque, M. E. U.; Dey, S.; Guha, A. K.; Kim, C. K.; Lee, B. S.; Lee, H. W. J. Org. Chem. 2007, 72, 5493. (b) Hoque, M. E. U.; Lee, H. W. Bull. Korean Chem. Soc. 2007, 28, 936. (c) Dey, N. K.; Han, I. S.; Lee, H. W. Bull. Korean Chem. Soc. 2007, 28, 2003. (d) Hoque, M. E. U.; Dey, N. K.; Kim, C. K.; Lee, B. S.; Lee, H. W. Org. Biomol. Chem. 2007, 5, 3944. (e) Dey, N. K.; Hoque, M. E. U.; Kim, C. K.; Lee, B. S.; Lee, H. W. J. Phys. Org. Chem. 2008, 21, 544. (f) Lumbiny, B. J.; Lee, H. W. Bull. Korean Chem. Soc. 2008, 29, 2065. (g) Dey, N. K.; Hoque, M. E. U.; Kim, C. K.; Lee, B. S.; Lee, H. W. J. Phys. Org. Chem. 2009, 22, 425. (h) Dey, N. K.; Kim, C. K.; Lee, H. W. Bull. Korean Chem. Soc. 2009, 30, 975. (i) Hoque, M. E. U.; Guha, A. K.; Kim, C. K.; Lee, B. S.; Lee, H. W. Org. Biomol. Chem. 2009, 7, 2919. (j) Dey, N. K.; Lee, H. W. Bull. Korean Chem. Soc. 2010, 31, 1403. (k) Dey, N. K.; Kim, C. K.; Lee, H. W. Org. Biomol. Chem. 2011, 9, 717. (1) Barai, H. R.; Lee, H. W. Bull. Korean Chem. Soc. 2011, 32, 1939. (m) Hoque, M. E. U.; Lee, H. W. Bull. Korean Chem. Soc. 2011, 32, 1997. (n) Hoque, M. E. U.; Lee, H. W. Bull. Korean Chem. Soc. 2011, 32, 2306. (o) Adhikary, K. K.; Lumbiny, B. J.; Dey, S.; Lee, H. W. Bull. Korean Chem. Soc. 2011, 32, 2628. (p) Hoque, M. E. U.; Lee, H. W. Bull. Korean Chem. Soc. 2011, 32, 3245. (q) Barai, H. R.; Lee, H. W. Bull. Korean Chem. Soc. 2011, 32, 3355. (r) Hoque, M. E. U.; Lee, H. W. Bull. Korean Chem. Soc. 2011, 32,3880 .

8. (a) Hengge, A. C.; Onyido, I. Curr. Org. Chem. 2005, 9, 61. (b) Omakor, J. E.; Onyido, I.; vanLoon, G. W.; Buncel, E. J. Chem. Soc. Perkin Trans. 2 2001, 324. (c) Gregersen, B. A.; Lopez, X.; York, D. M. J. Am. Chem. Soc. 2003, 125, 7178. (d) Hondal, R. J.;
Bruzik, K. S.; Zhao, Z.; Tsai, M. D. J. Am. Chem. Soc. 1997, 119, 5477.

9. (a) Williams, A. Free Energy Relationships in Organic and Bioorganic Chemistry; RSC: Cambridge, UK, 2003; Chapter 7. (b) Ruff, A.; Csizmadia, I. G. Organic Reactions Equilibria, Kinetics and Mechanism; Elsevier: Amsterdam, Netherlands, 1994; Chapter 7. (c) Oh, H. K.; Lee, J. M.; Lee H. W.; Lee, I. Int. J. Chem. Kinet. 2004, 36, 434. (d) Oh, H. K.; Park, J. E.; Lee, H. W. Bull. Korean Chem. Soc. 2004, 25, 1041. (e) Oh, H. K.; Ku, M. H.; Lee, H. W.; Lee, I. J. Org. Chem. 2002, 67, 8995. (f) Castro, E. A.; Angel, M.; Campodonico, P.; Santos, J. G. J. Org. Chem. 2002, 67, 8911. (g) Castro, E. A.; Pavez, P.; Santos, J. G. J. Org. Chem. 2002, 67, 4494. (h) Oh, H. K.; Ku, M. H.; Lee, H. W.; Lee, I. J. Org. Chem. 2002, 67, 3874. (i) Castro, E. A.; Pavez, P.; Santos, J. G. J. Org. Chem. 2002, 67, 3129. (j) Castro, E. A.; Pavez, P.; Arellano, D.; Santos, J. G. J. Org. Chem. 2001, 66, 6571. (k) Spillane, W. J.; McGrath, P.; Brack, C.; O’Byrne, A. B. J. Org. Chem. 2001, 66, 6313. (1) Koh, H. J.; Han, K. L.; Lee, H. W.; Lee, I. J. Org. Chem. 2000, 65, 4706. (m) Humeres, E.; Debacher, N. A.; Sierra, M. M. D.; Franco J. D.; Shutz, A. J. Org. Chem. 1998, 63, 1598. (n) Baynham, A. S.; Hibbert, F.; Malana, M. A. J. Chem. Soc., Perkin Trans 2 1993, 1711.

10. The cross-interaction constants (CICs), $\rho_{\mathrm{XY}}$, of the pyridinolyses of $\mathrm{S}\left(\mathrm{EtO}, \mathrm{YC}_{6} \mathrm{H}_{4} \mathrm{O}\right)($ ref. $1 \mathrm{~s}), \mathrm{S}\left(\mathrm{PhO}, \mathrm{YC}_{6} \mathrm{H}_{4} \mathrm{O}\right)($ ref. $1 \mathrm{j})$, and $\mathrm{S}(\mathrm{Ph}$, $\mathrm{YC}_{6} \mathrm{H}_{4} \mathrm{~S}$ ) (ref. 1r) in $\mathrm{MeCN}$ are consistent with the proposed mechanism. Refs. for CIC: (a) Lee, I. Chem. Soc. Rev. 1990, 19, 317. (b) Lee, I. Adv. Phys. Org. Chem. 1992, 27, 57. (c) Lee, I.; Lee, H. W. Collect. Czech. Chem. Commun. 1999, 64, 1529. 